\title{
Elements which precipitate conjugal violence: the discourse of men in criminal prosecution
}

\section{Elementos que precipitam a violência conjugal: o discurso de homens em processo criminal Elementos que precipitan la violencia conyugal: el discurso de hombres en proceso criminal}

How to cite this article:

Lírio JGS, Pereira A, Gomes NP, Paixão GPN, Couto TM, Ferreira AS. Elements which precipitate conjugal violence: the discourse of men in criminal prosecution. Rev Esc Enferm USP. 2019;53:e03428. DOI: http://dx.doi.org/10.1590/S1980-220X2017036203428

Josinete Gonçalves dos Santos Lírio ${ }^{1}$

Álvaro Pereira ${ }^{1}$

Nadirlene Pereira Gomes ${ }^{1}$

D Gilvânia Patricia do Nascimento Paixão ${ }^{2}$

D Telmara Menezes Couto ${ }^{1}$

D Andrey da Silva Ferreira ${ }^{1}$

1 Universidade Federal da Bahia, Escola de Enfermagem, Salvador, BA, Brazil.

${ }^{2}$ Universidade do Estado da Bahia, Senhor do Bonfim, BA, Brazil.

\section{ABSTRACT}

Objective: Unveiling the precipitating elements of conjugal violence based on the discourse of men undergoing criminal prosecution. Method: This is a qualitative study developed in a Domestic Violence and Family Violence Campaign against Women from Salvador, Bahia, Brazil. Results: We interviewed 23 men. The following central ideas emerged: children and family interference; change in woman's behavior; feeling of ownership; discovery of extramarital affairs of women; absence of marital sexual intercourse; and use of alcohol and other drugs by men. Conclusion: Several elements precipitate marital violence according to the mens' discourse. Knowing these elements can subsidize actions for preventing the phenomenon, especially from implementing peaceful conflict resolution strategies.

\section{DESCRIPTORS}

Violence Against Women; Family Conflict; Intimate Partner Violence; Family Nursing. 


\section{INTRODUCTION}

Disrespectful conflict resolution consists of a mobilizing amount of violence worldwide, including in marital relations. Considering the importance of preventing this phenomenon, in which men represent the main tormentors, there is a need for actions which enable men and women to deal with conflicts in a non-violent way ${ }^{(1-3)}$. For this, it is necessary to know about the elements which predispose these violent situations.

Considering that interpersonal coexistence is permeated by different ways of thinking and given the individuality of each subject ${ }^{(1)}$, it can be said that conflicts are understood as the antagonistic state of ideas and/or interests, being intrinsic to human relationships, and instruments for changes in the majority of cases ${ }^{(2)}$. However, it is important to consider how these conflicts are handled, since they can lead to disrespectful actions when they are not resolved in a peaceful manner, in turn resulting in violence ${ }^{(3)}$.

Men are mainly involved in situations of violence around the world. Brazilian studies point to the male gender as the most involved in interpersonal violence, whether in public spaces, at work and/or in the family institution ${ }^{(4)}$. An international study of 219 countries and territories has shown that men are at the same time the main victims and perpetrators of urban violence. Data show that in 2012 there were 437 thousand deaths of people for homicides, and that $79 \%$ were involving the male gender. Men themselves were the killers in $95 \%$ of these murders ${ }^{(5)}$.

Among all forms of interpersonal violence, that which occurs within affective-loving relationships has the greatest magnitude, being responsible for the death of thousands of women around the world. In Brazil, marital violence resulted in 17,581 deaths of women in the period from 2011 to 2013, an average of 5,860 deaths of women per year, and 16 deaths per day ${ }^{(6)}$.

In addition to mortality, this situation also has repercussions on the lives of men, as evidenced in a study carried out in Hong Kong in which men living within a situation of conjugal violence were more likely to develop health problems in the physical and mental spheres ${ }^{(7)}$.

As abovementioned, the repercussions of violence are also present in the lives of men who experience the phenomenon, with another example in a study carried out in Salvador, Bahia, which revealed that the experience of violence on the part of men caused mental/physical illness such as: sadness, low self-esteem, apathy, depression, tachycardia, hypertension, headache and gastrointestinal problems. Although the repercussions reported by men center on the experience of pre-trial detention (which also leads to stigma and negatively interferes with future employability), it cannot be disregarded that this reality is associated with conjugal violence ${ }^{(8)}$. Due to this scenario, there is a worldwide effort to prevent and/or reduce this problem which represents a relevant public health issue.

Understanding that affectionate-loving conflicts resolved in a non-peaceful way generate conjugal violence ${ }^{(9)}$, and that elucidating the elements that predispose these affectionateloving conflicts is essential to face the phenomenon, this study is based on the following guiding question: What are the precipitating elements of marital violence? Since conjugal violence is a mutual phenomenon whose production of scientific knowledge mostly focuses on the perspective and experience of women, giving a voice to men (the other subject of the relationship) is necessary to better understand the theme. In this sense, this study aims to unveil the precipitating elements of conjugal violence from the discourse of men undergoing criminal prosecution.

\section{METHOD}

\section{StUdD DESIGN}

This study has implemented a qualitative approach linked to the anchor project, entitled "Re-education of men and women involved in criminal prosecution: a strategy to combat marital violence" (Reeducaşão de homens e mulheres envolvidos em processo criminal: estratégia de enfrentamento da violencia conjugal). This project aims to develop social technology for preventing and coping with marital and gender violence together with the Domestic Violence and Family Violence against Women legal department.

\section{SCENARIO}

The locus of the study was the Domestic Violence and Family Violence against Women legal department from Salvador, Bahia, Brazil. The participants were 23 men who were undergoing criminal prosecution for marital violence in the aforesaid division and participated in the Reflexive Group for Men (RGM). Participant eligibility was based on the following criteria: to be undergoing criminal prosecution from the division in question; having been arrested as a result of conjugal violence; and presenting good emotional conditions. The RGM was planned and developed through nine fortnightly meetings, with an average duration of 2 hours each. These spaces were predominantly led by nursing professionals linked to the Violence, Health and Quality of Life Study Group, seeking to stimulate the understanding of the social gender construction in men, which nurtures the belief of male power and naturalizes violence against women. It was also a timely environment to foster self-responsibility for their criminal conduct and the health implications of all involved. It is noteworthy that this was the first group developed, with others being predicted by the anchor project.

\section{DATA COLLECTION}

The researchers explained about the RGM methodology in the first meeting. In this opportunity, all the participants were informed about the research, being clarified as to the objective and relevance of the study; benefits and potential risks; their right to decide whether or not to collaborate in the research, and that their refusal would not prevent them from participating in the RGM. The participants' anonymity was further clarified - which are coded with the letter "I", referring to the testimonies from the individual interview, followed by an Arabic numeral. 
The interview followed a semi-structured form containing sociodemographic aspects (age, color, religion, education, income, occupation, work situation), in order to characterize the participants, and the following guiding question: In the records of your trial there are situations which characterize conjugal violence. What elements do you attribute to this violence? The interviews were conducted by the researcher in a reserved room at the study site, and were recorded using a portable recorder. The data collection period occurred from July to December 2015.

\section{DATA ANALYSIS AND PROCESSING}

After data collection, the interviews were transcribed and organized with the help of Nvivo-11 software and then systematized through the Collective Subject Discourse (CSD), a technique which enables constructing a single speechsynthesis representative of the collectivity. Some steps were subsequently performed to do this, namely: 1) transcription of the interviews; 2) analysis of the material, with the Key Expressions (KE) being extracted from each testimony, and from them naming the Central Ideas - CI; 3) to compose the various discourse-syntheses, denominated Discourse of the collective subject from the $\mathrm{CI}$ and $\mathrm{KE}$. It is possible to insert collective thinking into a single discourse with the use of these two methodological figures, which this being a scientific product ${ }^{(10)}$.

\section{ETHICAL ASPECTS}

All the ethical precepts of human research recommended by Resolution 466/12 of the National Health Council were fulfilled. The RGM participants agreed to collaborate with the study, and duly signed the Informed Consent Form. The research was approved by the Ethics Committee in Research of the Nursing School of the Universidade Federal da Bahia, under the opinion n. 877.905/2014.

\section{RESULTS}

The 23 participants in the study were mostly young black adults with low socioeconomic status and only six had completed high school. The conjugal aspects reveal that they lived in a stable union before prison, but at the moment being separated in their marriage. Among those interviewed, 20 reported having children with the woman who had filed charges against them.

From the collective discourse of men in criminal proceedings, it was possible to unveil the various precipitators of conjugal violence, arranged in the central ideas which follow.

\section{Central idea 1 - Childiren and family interference}

Children reveal themselves as precipitators of marital violence by predisposing a change in the couple's routine and by different perceptions about how to raise them. Children born from a previous relationship was another revealed interference. There is also the influence of the family in relationship of the couple, which may precipitate the occurrence of violence, because from the men's perception marital problems only concern the couple. These aspects can be highlighted in the following discourse:

Arguments always happen because of the children. We started to fight a lot after they were born, because the routine began to become very tiring, very stressful, she didn't want to leave the house, and when I left she fought with me. In addition, we think differently about their upbringing. My daughters were arriving home late at night, that's wrong! I like my things right. Women can't stay out in the street like this. I also caught my son playing football, missing classes, and said something about it, but she [wife] always turns a blind eye. We also argued over my wife's daughter who I didn't want living in our house. Another thing that made me angry and we were always fighting about was when her sisters and mother got involved, when her family came into the relationship and voiced their opinions, because our problems are ours that we have to solve, and I couldn't stand that! (E1, E3, E12, E13, E14, E18, E20, E21, E23).

\section{Centrall idea 2 - Change in the woman's behavior}

The mens' discourse also showed that a change in the woman's way of acting, over time, led to the occurrence of violence. The female remodeling was justified by facts such as studying, friendships and the non-performance of domestic tasks that she once performed.

When we met it was a sea of roses, there was a lot of affection and caring, but with the passage of time it didn't exist anymore. Things have changed! She met new people, made new friends, started studying, went out with her friends, she slept away from home and she changed. Before, when I got home from work, the house was clean, the food was made and the clothes had been ironed, but over time this stopped happening. I'd come home from work and had to keep asking for things, sometimes I had nothing to eat. I was feeling like a needy man without attention and it irritated me, I lost my head. A guy arrives home tired from work and sees the whole house messy, sink full of dishes, no one can stand this! (E02, E03, E04, E16, E19, E20).

\section{Central idea 3 - Feeling of possession}

The feeling of possession was also revealed as a causing agent of violence, which is evidenced by non-respect for the individuality of the other when taking their cellphone and attempting to keep their companion at home. There is also non-acceptance by the man of "inappropriate" clothes worn by his partner/wife for causing him social embarrassment, and also violating the individuality of women. These factors end up leading to the occurrence of various forms of violence, according to the following discourse:

We always had a very good relationship, the problem was jealousy we had for each other. It was sick, there was no trust in either of us, it was like an object, a possession, and so we argued a lot. She always looked at my cell phone to check it and wanted me to use it on speaker. Once the cell phone had a password, when she saw that she could not unlock it, she broke my phone. She wanted me to stay home Saturday, but I went out with my friends, and when I was late, she said I was with another woman. One day, I got home and she had cut all my clothes with a knife. It made me furious, 
I lost control and went to beat her. We also fought a lot because of her clothes. I will not agree to my wife wearing a really short dress to go out, I think she should have common sense, think, "I'm with my husband, I will behave a little better." I seriously argued with her once because she bought very thin pants. I told her not to wear them, but she ended up wearing them. I was on the street, I saw her getting on the bus and people were commenting. I didn't even go to work that day because I was so upset (E3, E8, E10, E12, E13, E15, E18, E19, E21, E22).

\section{Central Idea 4 - Discovering extramarital RELATIONSHIPS OF WOMAN}

The following report shows that the discovery of infidelity in the marital relationship was one of the motivating elements of intimate partner violence.

In the first years that we started to date everything was good, until I discovered the betrayals. Everyone called me a sucker because they warned me, but I didn't listen. I only found out that she was cheating on me later, when I picked up her phone and heard him [lover] saying, "love, will you come today?" When she saw me with her cell phone, she came at me aggressively and at that moment I punched her. Then, to get revenge and show everyone that I can live without her, I made out with a woman in front of her [in front of his former companion] (E5, E6, E11, E14, E16).

\section{Central idea 5 - Absence Of marital seXual INTERCOURSE}

The absence of sexual relations was a frequent motive in the male discourse, since men often understand that there is a sexual obligation of the companion towards him. The lack of sex, often associated with religious dedication, is seen as a debilitating factor in the relationship, thus promoting the occurrence of marital violence.

My wife changed after becoming religious. She entered the chur$c h$, and things started to get difficult in our house. We men are dependent on sex. I began to push her for it, and she said: 'God first'. I really don't understand that reaction from her. To speak of God is one thing, but to fail to do your obligations, your duties, is another. The woman has an obligation to have sex with her man. How can a couple live without sex? I'll think what if my wife doesn't want to have sex with me? I will imagine that she is with someone else [referring to betrayal]. A lack of sex broke down the relationship. There was a moment when we would only argue: she would say something and I would respond rudely because I was angry and she wouldn't give me what I wanted. I started doing everything she didn't like, just to piss her off, and as I wasn't getting any at home, I looked for sex in the street (E1, E5, E6, E7, E8, E11, E18, E20).

\section{Central idea 6 - Use of AlCohol AND other dRUGS BY MEN}

The collective discourse shows that the use of licit and illicit drugs favors initiation of conjugal violence, since the man states that he loses control of himself when using these substances.
Drinking and drugs contributed a lot to us fighting. I started going out on the street getting high, every day, and couldn't control myself. I would come home with my head full of cocaine or too much booze, and if she asked me anything, I would scream, fight and beat her. I couldn't control myself. The drug transformed me (E1, E3, E4, E5, E6, E18, E22).

\section{DISCUSSION}

Among the precipitators of conjugal violence unveiled in the study, the children are configured as promoters of changes in the couple's routine which causes disagreements and arguments to occur, mainly due to the stressful routine, according to the male discourse. Research which investigated the national and international scientific production on the relationship between conjugality and parenting revealed that this routine change is due to the transition of roles: the spouses are now mother and father, and their expectations and aspirations, once focused on each other, are now on the arrival of a new member. Thus, conflicts arise with parenting which interfere in the love-affection relationship ${ }^{(11)}$. The findings of this study corroborate the findings of a study of women living in the city of Salvador, Bahia, Brazil, which reveals that there was a change in the marital relationship after the arrival of children, predisposing the couple to disagreements and the occurrence of marital violence ${ }^{(3)}$.

In addition to the changed dynamics, divergences also occur because parents have different perceptions about the way their children are raised and which varies according to gender, as mentioned in the first discourse; a fact that is rooted in hegemonically established gender roles. Accordingly, research developed in the United States has revealed that gender social representations guide parents in raising their children. In this context, girls are prepared to exercise domestic care as well as reproduce subservient behaviors. For boys, they are taught the necessary tasks to become strong and independent individuals, performing functions in the public sphere, especially in providing for the home. Parental attitudes which deviate from this pattern, if not accepted by both, lead to conflicts between the couple $^{(12)}$, and strategies are necessary for those responsible to find consensus which focus on the best for the lives of the children.

If on the one hand the study indicates conflicts related to divergence in raising the children, on the other hand it points out the non-accountability of step-parents as being responsible in the caring process. The findings reveal that some men do not accept the cohabitation of children from previous marital relationships in the same house where he resides with the child's mother. Research carried out with women in conjugal violence situations showed that they also do not accept to live with children from other relationships of the partner, not feeling responsible for participating in their raising ${ }^{(3)}$. Such situations may be associated with the insecurity related to fear of new involvement with expartners, which will further aggravate the couple's misunderstandings. One should also consider the fact that the family is the first social institution responsible for forming 
an individual's identity, as the paternal and maternal figures are essential in their emotional and cognitive development process. In this sense, it is vital that the new family models ensure a harmonious environment for children.

External views on child raising have also emerged as elements which instigate marital conflict. In this sense, the collective discourse shows family interference as an element which predisposes the occurrence of conjugal violence, since there is a male understanding that domestic problems are intimate. A study with men and women in João Pessoa, Paraíba, Brazil, also showed that the excessive interference by grandparents in raising grandchildren can generate conflicts between parents ${ }^{(13)}$. Faced with the identification of this scenario, it is important for health professionals to be attentive to changes in family relationships so they can intervene early in conflict resolution.

The study also calls attention to family involvement in the marital relationship, which also motivates fights occurring. In such cases, external interference should also be considered in order to evaluate them as protective or conflicting events. Corroborating the interference in relationships, a study shows that the family of origin exerts considerable influence on the men, predisposing changes in their way of acting with their partner ${ }^{(14)}$. Thus, articulation with the relatives of the spouses can be an important strategy in the sense of avoiding conjugal violence.

Regarding changes in behavior, men complain that women do not take on the role of wife, mother and housewife, especially when they fail to play roles considered inherent to the female gender. These roles are validated by gender inequality, which also designates a sexual division of labor in our society. In this context, the private space is assigned to women, who perform the reproduction work, while the public spaces are reserved for men in which the production tasks are developed. It is worth mentioning that domestic activity is considered reproductive work, with no market value and social prestige, and is therefore a devalued work which leads to female submission ${ }^{(15)}$.

When a woman acts differently from social standards, these actions are not accepted by men, who understand that it is the wife's duty to play roles which were once readily done in the past, such as those at home. A study carried out with men reported at the women's specialized police station in Rio de Janeiro, Brazil, revealed that one of the justifications given by them for committing domestic violence was that their companion did not comply with household chores. This irritated them, because they believed that these duties were the duty of their companion ${ }^{(16)}$, which is also a situation that is similar to the findings in this research. In this regard, the triple working hours of women are noted, which in addition to formal employment, they have to carry out domestic tasks of caring for the home and children, while men only remain bound to public space.

In the list of gender inequalities, there is the understanding that man can decide for his wife, even with interference in their studies and their friendships. National research legitimizes these findings by asserting that men try to curtail women's freedom of choice, as well as control their social relationships, determining how they should act and with whom they should maintain friendly relationships. In addition, they forbid them from going to her family's home ${ }^{(3,17)}$. A study carried out in 27 African countries also associates marital conflicts with women's decision to work for pay, because the partner fears that she'll become independent and gain greater bargaining power within the family, thus assuming a socially attributed male role ${ }^{(18)}$. These examples are anchored in the idea of ownership of the other, which gives rise to the feeling of possession. The existing symbolic violence is thus materialized based on male domination and possession over the female body, understood as his right ${ }^{(19)}$.

Another example of male ownership and control refers to the imposition of clothing to their female companions. Research has revealed men's attempts to define how their wives should dress themselves, and showed that some of them contradict such a masculine order, wearing clothes which displease their companion ${ }^{(3)}$. When this happens, men tended to act aggressively, justifying such behavior as feeling embarrassed by "others", as well as blaming his partner for disobedience to his determination. This socially shared belief that the man is the owner of the woman make them vulnerable corroborating her enduring abusive conjugal relations.

It should be noted that on several occasions, male dominance is understood as an expression of love. Romantic jealousy, approached by several international and national surveys, arises when there is an ideation of a threat to the relationship $^{(12,20)}$. Such a threat can be perceived when the partner does not accept that her partner leaves the house because she imagines that he will meet other women. Qualitative research conducted in the United States also reinforces that jealousy is motivated by the fear of losing the spouse to another person, a risk factor for the occurrence of violent acts ${ }^{(12)}$, which deserves to be prioritized among the themes to be reflected from health education actions focused on relationships based on trust and respect between men and women.

In an attempt to confirm the ideation of infidelity, the discourse reveals that women search through their spouse's cell phone without their permission, which characterizes an invasion of privacy. It should be noted that the current situation of greater social network use facilitated by portable cellphones favors both the occurrence of extramarital relationships and their discoveries ${ }^{(20)}$.

Reactions differ between women and men when extramarital involvement is discovered. Women are more likely to internalize what they have experienced, and therefore somatize the injury. This impairs their physical and mental health, since they trigger episodes such as headache, epigastric pain, insomnia, anxiety, depression, and may even evolve to suicide attempt. On the other hand, men take a violent stance in response to the perception that their reputation has been offended, and must restore it socially, which lead to crimes of passion $^{(21)}$.

The findings of this study show that after discovering his partner's infidelity, a man acts aggressively, believing that the betrayal has damaged his manhood. Such conduct is an inversion of values, because in order to "rescue his wounded masculinity", violent action leads the man into 
being a criminal. In addition, the discourse shows that while they judge the betrayal of their partner as wrong, they also cheat, revealing a naturalization/legitimation of male extra-marital relations, which ratifies the findings of other studies $^{(3,22)}$. Added to this are cases in which men imagine their partner cheating, such as when they question their female partner's refusal to perform sexual relations. Such association was also revealed in testimonies of men in the Specialized Department of Attention to Women (DEAM - Delegacia Especializada de Atendimento à Mulher) of Rio Grande do Sul, Brazil(23).

Associated to the refusal of sexual relations by women, male discourse points to religious dedication, which raises the man's discontent, who believes that it is the woman's duty to satisfy him sexually. This is also a shared perception among women who give in to sexual acts, even without wishing it, because they also understand it to be their obligation as a wife, predisposing them to conjugal rape ${ }^{(3)}$.

Among the factors which make conjugal violence occurrence more vulnerable, the use of chemical substances appears to increase the occurrence of conjugal rape ${ }^{(24-25)}$. However, we cannot say that drug use alone generates violence, mainly due to its intensifying character on people who already show aggressive behavior. The use of alcohol and drugs also appeared in this study as a factor which is capable of precipitating marital violence. The association between the use of these substances and marital violence has already been recognized in national ${ }^{(3,26)}$ and international studies ${ }^{(27-28)}$.

\section{CONCLUSION}

This study enabled unveiling the precipitating elements of conjugal violence from the CSD of men undergoing criminal prosecution: children and family interference; women's behavior change; feeling of ownership; discovery of extramarital affairs of women; absence of marital sexual intercourse; and use of alcohol and other drugs by man.
Although the study is limited by only representing the discourse of a group of men inserted in a certain cultural context of the Brazilian Northeast, elucidation of the precipitating elements of conjugal violence are essential to think of ways for peaceful resolution of conflicts. Considering that the scientific evidence mostly portrays the women's perspective, such findings are innovative by contemplating the male perspective on the phenomenon, and can contribute to knowledge production about the prevention of domestic violence.

In addition to violence, it should be pointed out that the discourses did not show other strategies for solving problems. This reality is rooted in a social construction which validates violent ways of acting and dictates different roles and powers for men and women. Faced with this scenario, there is a need for the involvement of multidisciplinary institutions, which when articulated can develop a comprehensive and effective work to change behavior within family and social relationships.

The health sector therefore includes being able to incite prevention actions by recognizing that there are elements which predispose domestic violence occurrence, in addition to being the gateway for treating people who are hurt due to this phenomenon. As an example, the use/abuse of alcohol and other drugs, which in addition to directly causing health problems, is still associated with precipitating violence. In the education field, the need to work with the family is inferred, especially children and adolescents, so that they can learn new models of relationships aiming at gender equality, freeing themselves from the current paradigms and the continuity of relationship models of power/ domination. The judicial area is also important because spaces can be provided through articulated work with other services for men and women who are already involved in a judicial/criminal process to rethink their conduct and seek healthier relationships which are permeated by dialogue and free from violence, which is even considered by the Maria da Penha Law.

\section{RESUMO}

Objetivo: Desvelar os elementos precipitadores de violência conjugal, a partir do discurso de homens em processo criminal. Método: Trata-se de um estudo de abordagem qualitativa, desenvolvido em uma Vara de Violência Doméstica e Familiar contra Mulher de Salvador, Bahia, Brasil. Resultados: Foram realizadas entrevistas com 23 homens. Emergiram as ideias centrais: filhos e interferência da família; mudança no comportamento da mulher; sentimento de posse; descoberta de relações extraconjugais da mulher; ausência de relação sexual marital; e uso de álcool e outras drogas pelos homens. Conclusão: Segundo o discurso dos homens, vários são os elementos que precipitam a violência conjugal. Conhecer esses elementos pode subsidiar ações para a prevenção do fenômeno, sobretudo a partir de estratégias pacíficas de resoluções de conflitos.

\section{DESCRITORES}

Violência contra a Mulher; Conflito Familiar; Violência por Parceiro Íntimo; Enfermagem Familiar.

\section{RESUMEN}

Objetivo: Desvelar los elementos precipitadores de violencia conyugal mediante el discurso de varones en proceso criminal. Método: Se trata de un estudio de abordaje cualitativo, desarrollado en un Juzgado de Violencia Doméstica y Familiar contra la Mujer de Salvador, Bahía, Brasil. Resultados: Se llevaron a cabo entrevistas con 23 hombres. Emergieron las ideas centrales: hijos e interferencia de la familia; cambio en el comportamiento de la mujer; sentimiento de posesión; descubierta de relaciones extraconyugales de la mujer; ausencia de relación sexual marital; y adicción al alcohol y a otras drogas por los hombres. Conclusión: Según el discurso de los varones, distintos son los elementos que precipitan la violencia conyugal. Conocer dichos elementos puede subsidiar acciones para la prevención del fenómeno, sobre todo desde unas estrategias pacíficas de resoluciones de conflictos.

\section{DESCRIPTORES}

Violencia contra la Mujer; Conflicto Familiar; Violencia de Pareja; Enfermería de la Familia. 


\section{REFERENCES}

1. Friedrich TA, Webe MAL. Gestão de conflitos: transformando conflitos organizacionais em oportunidades [Internet]. Porto Alegre: Conselho Regional de Administração do RS; 2014 [citado 2017 ago. 22]. Disponível em: http://crars.org.br/artigos_interna/gestao-de-conflitostransformando-conflitos-organizacionais-em-oportunidades-41.html

2. Kim EJ, Yamaguchet A, Kim MS, Miyahara A. Effects of taking conflict personally on conflict management styles across cultures. Pers Individ Dif. 2015;72:143-9. DOI: https://doi.org/10.1016/j.paid.2014.08.004.

3. Paixão GPN, Gomes NP, Diniz NMF, Couto TM, Vianna LAC, Santos SMP. Situations which precipitate conflicts in the conjugal relationship: the women's discourse. Texto Contexto Enferm [Internet]. 2014 [cited 2017 Aug 13]; 23(4):1041-9. Available from: http://www.scielo.br/ scielo.php?script=sci_arttext\&pid=S0104-07072014000401041\&lng=en

4. Melo ACM, Garcia LP. Care for young victims of assault in public emergency services in 2011: sex differences. Ciênc Saúde Coletiva [Internet]. 2017 [cited 2017 Aug 13]; 22(4):1333-41. Available from: http://www.scielo.br/scielo.php?pid=S1413-81232017002401333\&script=sci_ arttext\&tlng=en

5. United Nations Office on Drugs and Crime. Escritório de Ligação e Parceria no Brasil. Cerca de 437 mil pessoas foram assassinadas no mundo em 2012, de acordo com novo estudo do UNODC [Internet]. Viena; 2014 [citado 2017 ago. 22]. Disponível em: https://www. unodc.org/lpo-brazil/pt/frontpage/2014/04/10-some-437000-people-murdered-worldwide-in-2012-according-to-new-unodc-study.html

6. Garcia LP, Silva GDM. Mortalidade de mulheres por agressões no Brasil: perfil e estimativas corrigidas (2011-2013) [Internet]. São Paulo: IPEA; 2016 [citado 2017 ago. 22]. Disponível em: http://www.ipea.gov.br/portal/images/stories/PDFs/TDs/td_2179.pdf

7. Zhang H, Wong WC, Ip P, Fan S, Yip PS. Intimate partner violence among Hong Kong young adults: prevalence, risk factors, and associated health problems. J Interpers Violence. 2015;30(13):2258-2277. DOI: 10.1177/0886260514552442

8. Sousa AR, Pereira A, Paixão GPN, Pereira NG, Campos LM, Couto TM. Repercussions of imprisonment for conjugal violence: discourses of men. Rev Latino Am Enfermagem [Internet]. 2016 [cited 2018 May 14];24:e2847. Available from: http://www.scielo.br/scielo. php?script=sci_arttext\&pid=S0104-11692016000100440\&lng=en

9. Shirazian TMD, Afzal ODO, Viswanathan, NMD. Community health workers understanding and attitudes regarding intimate partner violence in the Dominican Republic. Obstet Gynecol. 2015;125:64. DOI: 10.1097/01.AOG.0000463763.95565.79

10. Lefevre F, Lefevre AMC. Discurso do sujeito coletivo: um novo enfoque na pesquisa qualitativa. Caxias do Sul: Educs; 2005.

11. Cecílio MS; Comin FS. Relações entre conjugalidade e parentalidades adotiva e biológica. Psico [Internet]. 2013 [citado 2017 ago. 12];44(2):245-56. Disponível em: http://revistaseletronicas.pucrs.br/ojs/index.php/revistapsico/article/view/11515/9643

12. Edwards KM, Victoria LB, Elizabeth AM, Katherine MS. Rural young adults' lay theories of intimate partner violence: a qualitative examination. Am J Community Psychol. 2016;58(3-4):434-45. DOI: 10.1002/ajcp.12095

13. Lins ZMB, Salomão NMR, Lins, SLB, Carneiro TF, Eberhardt AN. O papel dos pais e as influências externas na educação dos filhos. Rev SPAGESP [Internet]. 2015 [citado 2017 ago. 22];16(1):43-59. Disponível em: http://pepsic.bvsalud.org/scielo.php?script=sci_arttext\&pid $=$ S1677-29702015000100005

14. Quissini C, Coelho LRM. A influência das famílias de origem nas relações conjugais. Pensando Fam [Internet]. 2014 [citado 2017 ago. 10];18(2): 34-47. Disponível em: http://pepsic.bvsalud.org/scielo.php?script=sci_arttext\&pid=S1679494X2014000200004\&lng=pt\&nrm=iso

15. Santos G, Buarque C. O que é gênero? In: Vanin IM, Gonçalves T, organizadores. Caderno gênero e trabalho [Internet]. Salvador: Redor; 2006. p. 25-34 [citado 2016 set. 19]. Disponível em: http://www.neim.ufba.br/site/arquivos/file/formacaotrabalhadores.pdf Acesso em: 19 set. 2016

16. Cortez MB, Souza L. A violência conjugal na perspectiva de homens denunciados por suas parceiras. Arq Bras Psicol [Internet]. 2010 [ citado 2017 ago. 22];62(2):129-42. Disponível em: http://pepsic.bvsalud.org/pdf/arbp/v62n2/v62n2a12.pdf

17. Balduino RCP, Zandonadi AC, Oliveira ES. Violência doméstica: fatores implícitos na permanência em situação de sofrimento. Rev Farol [Internet]. 2017 [citado 2017 jul. 01];3(3): 111-25. Disponível em: http://revistafarol.com.br/index.php/farol/article/view/39

18. Alesina A, Brioschi B, Ferrara EL. Violence against women: a cross-cultural analysis for Africa [Internet]. 2016 [cited 2017 Jun 05]. Available from: http://www.nber.org/papers/w21901

19. Scarduzio JA, Carlyle KE, Harris KL, Savage MW. "Maybe She Was Provoked": exploring gender stereotypes about male and female perpetrators of intimate partner violence. Violence Against Women. 2017;23(1):89-113. DÖ: 10.1177/1077801216636240

20. Canezin PFM, Almeida T. O ciúme e as redes sociais: uma revisão sistemática. Pensando Fam [Internet]. 2015 [citado 2017 jul. 14];19(1):142-55. Disponível em: http://pepsic.bvsalud.org/pdf/penf/v19n1/v19n1a12.pdf

21. Conceição BRT, Martins CR, Freitas RB. “O ciúme romântico entre gêneros: uma visão sociopsicológica." Rev Psicol Foco [Internet]. 2015 [citado 2017 jun. 03];7(9):53-66. Disponível em: http://revistas.fw.uri.br/index.php/psicologiaemfoco/article/view/1558

22. Lammers J, Maner J. Power and attraction to the counternormative aspects of infidelity. J Sex Res. 2016;53(1):54-63. DOI: $10.1080 / 00224499.2014 .989483$

23. Costa CB, Falcke D, Mosmann CP. Conflitos conjugais em casamentos de longa duração: motivos e sentimentos. Psicol Estud [Internet]. 2015 [citado 2017 abr. 05];20(3):411-23. Disponível em: http://www.redalyc.org/articulo.oa?id=287145646008

24. Barros CRS, Schraiber LB. Intimate partner violence reported by female and male users of healthcare units. Rev Saúde Pública [Internet]. 2017 [cited 2017 Aug 13];51:7. Available from: http://www.scielo.br/scielo.php?script=sci_arttext\&pid=S0034-89102017000100203\&lng=en

25. Wilson IM, Graham K, Taft A. Living the cycle of drinking and violence: a qualitative study of women's experience of alcohol related intimate partner violence. Drug Alcohol Rev. 2017;36(1):115-24. DOI: 10.1111/dar.12405

26. Amaral LBM, Vasconcelos TB, Sá FE, Silva ASR, Macena RHM. Violência doméstica e a Lei Maria da Penha: perfil das agressões sofridas por mulheres abrigadas em unidade social de proteção. Rev Estudos Fem [Internet]. 2016 [citado 2017 jul. 29];24(2):521-40. Disponível em: http://www.scielo.br/scielo.php?script=sci_arttext\&pid=S0104-026X2016000200521\&lng=en\&nrm=iso 
27. Castro RJ, Cerellino LP, Rivera R. Risk factors of violence against women in Peru. J Fam Violence. 2017;32(8):807-15. DOI 10.1007/ s10896-017-9929-0

28. Shamu S, Gevers A, Mahlangu BP, Jama Shai PN, Chirwa ED, Jewkes RK. Prevalence and risk factors for intimate partner violence among Grade 8 learners in urban South Africa: baseline analysis from the Skhokho Supporting Success cluster randomised controlled trial. Int Health. 2016; 8(1):18-26. DOI: 10.1093/inthealth/ihv068.

Financial support:

Fundação de Amparo à Pesquisa do Estado da Bahia (FAPESB). 